\title{
SİBIRYA HALK ANLATILARININ "ÖLÜLER ÜLKESİ"NIIN İNSANLARI İLE İSLAMÎ ANLATILARIN CEHENNEM AZABI ÇEKEN İNSANLARI ARASINDA BİR KARŞILAŞTIRMA
}

\begin{abstract}
Prof. Dr. Mehmet AÇA*
ÖZ: Kahramanların, genellikle şeytan ya da kötü ruhlarla mücadele etmek için girdikleri "karanlıklar ülkesi”nde yolculuk ederken orada dünyada yaptıkları işlere göre cezalandırılan ve ödüllendirilen insanlarla karşılaşmaları, Sibirya halk anlatılarının karakteristik özelliklerinden birisidir. Kahramanların, şamanların yeraltı dünyasına yönelik yolculuklarını and1ran bu yolculukları sırasında karşılaştıkları bu türden manzaralar, Sibirya halklarının "günah", "ceza" ve "ölümden sonraki hayat”la ilgili inançlarını gözler önüne sermesi bakımından önemlidir. Uno Harva, Sibirya halklar1nın anlatılarındaki bu tür sahnelerin evrensel değerlerden kaynaklandığını ifade etmiştir. Sibirya halk anlatılarındaki bu sahnelerin benzerlerini, Harva'nın tespitini doğrular bir şekilde, cehennemle ilgili İslamî anlatılarda da görmek mümkündür. İslamî anlatılar (miraçnameler, masallar, kıssalar), cehennem azaplarına daha çok günahkâr kadınlar üzerinden odaklanmıştır. $\mathrm{Bu}$ tür anlatılardaki ceza nedenleri ve cezalandırma biçimleri ile Sibirya halk anlatılarındaki ceza nedenleri ve cezalandırma biçimleri arasında önemli benzerlikler vardır. Benzerlikleri, evrensel değerlerden yola çıkarak izah etmenin yanı sıra, Müslüman Türklerin Şamanizm, Budizm ve Maniheizm gibi dinlere ait inanç unsurlarını İslam inancına aktararak İslamileştirmeleriyle de izah etmek mümkündür. Bu çalışmada, Sibirya halk anlatılarındaki “ölüler ülkesi”nin insanları ile İslamî anlatıların cehennemde azap çeken insanları arasındaki benzerlikler ceza nedenleri ve ceza biçimleri açısından karşılaştırılmış, bu konuyu ele alan İslamî anlatıların kökenleri üzerinde durulmuştur.
\end{abstract}

Anahtar Kelimeler: Sibirya halk anlatıları, İslami anlatılar, ölüler ülkesi, cehennem, günah, azap.

* Marmara Üni., Fen-Edebiyat Fak. , TDE Böl. mehmet.aca@marmara.edu.tr 
12

TÜBAR XLI / 2017-Bahar / Prof. Dr. Mehmet AÇA

\title{
A Comparison Between the People of "Land of the Dead" in Siberian Folk Narratives and the People Suffering in the Hell in Islamic Narratives
}

\begin{abstract}
One of characteristic features in Siberian folk narratives is that when traveling through "the Land of Darkness" where they generally go in their struggle against the evil or bad spirits, the heroes encounter with people who are punished or rewarded according to the deeds they have done in the world. Such scenes which were encountered by heroes during their travels which resemble shamans' travels to the underworld are important in that they display beliefs of Siberian folks on "sin", "penalty", and "life after death". Uno Harva has stated that these sort of scenes in narratives of Siberian folks are rooted in universal values. It is also possible to see the similar scenes in Islamic narratives concerning hell and that certifies Harva's opinion. Islamic parables focus on hellish torture through wicked women, rather. There are significant similarities between penalty reasons and punishment forms in such parables and the ones in Siberian folk narratives. It is also possible to explain similarities by means of universal values and the fact that Muslim Turks have Islamicised their belief elements belonging to Shamanism, Buddhism and Manichaeism by transferring them into Islam religion, as well. In this study, we will compare similarities between the people of "the land of the dead" in Siberian folk narratives and the people suffering in the hell in Islamic parables in terms of penalty reasons and punishment forms, and will dwell on origins of Islamic parables which handle this subject.
\end{abstract}

Keywords: Siberian folk narratives, Islamic narratives, land of the dead, hell, sin, torment.

\section{Giriş}

Sibirya halklarının bazı kahramanlık destanlarında kahramanların, tıpkı Şamanlar gibi, kötü ruhlarla mücadele etmek için sık sık yeraltına indikleri anlatılmaktadır. Hatta kimi Yakut kahramanlık destanlarında mücadele tümüyle Alt Dünya'da geçmektedir. Genellikle kötü ruhlar tarafından kaçırılan Orta Dünya insanlarını kurtarmak için Alt Dünya'ya inen kahramanlar, burada kimileri işledikleri günahlardan dolayı işkencelere maruz bırakılarak cezalandırılan kimileri de sevaplarından dolayı ödüllendirilen ölmüş "1Şıklı dünya” insanları ile karşılaşırlar. Sibirya halklarının "ölüler ülkesi"nde işkence edilerek cezalandırılan insanlarının benzerlerine İslamî anlatılarda da rastlanmaktadır. İslamî anlatıların başında Hz. Muhammed'in miraca çıkışını anlatan miraçnameler, kıssalar ve masallar gelmektedir. Ayrıca, bazı hadislerde de benzer anlatımlara yer verilmiştir. Bu tür 
anlatılardaki ceza nedenleri ve cezalandırma biçimleri ile Sibirya halk anlatılarındaki ceza nedenleri ve cezalandırma biçimleri arasında benzerlikler görülür. Benzerlikleri, evrensel değerlerden yola çıkarak izah etmenin yanı sıra, Müslüman Türklerin Şamanizm ${ }^{1}$, Budizm ve Maniheizm ${ }^{2}$ gibi dinlere ait inanç unsurlarını İslam inancına aktararak İslamileştirmeleriyle de açılamak mümkündür. Bu çalışma, Sibirya halk anlatılarındaki "ölüler ülkesi”nin insanları ile İslamî anlatıların "cehennem"de azap çeken insanları arasındaki benzerlikleri tespit edip yorumlayacak, konuyla ilgili İslamî anlatıların kökenlerini sorgulayacaktır.

\section{Sibirya Halk Anlatılarının "Ölüler Ülkesi”nin İnsanları}

Fin-Ugor kavimleriyle Sibirya halklarının inanç dünyaları üzerine yaptığı çalışmalarla tanınan Harva, ölüler ülkesinde günahların cezalandırılması fikrine, Sibirya halklarının yeraltı ülkesinde geçen bazı destanlarında da rastlandığını kaydederek önce babası için yeraltı dünyasına inen bir gencin maceralarını anlatan bir Buryat destanından, daha sonra da Castrén'in Sayan bozkırlarından derlediği "yeraltı ülkesinin" efendisi İrlek Han'ın kızının kara bir tilki donuna girerek yeryüzüne çıkıp kötülükler yapışını ve Komdei-Mirgän adlı bir yiğidin bu tilkinin peşine düşüşünü anlatan bir Tatar (Hakas ya da Sagay) destanından söz etmiştir.

Buryat destanında babası için bir tilkinin kuyruğundan tutunarak yeraltı ülkesinin derinliklerine inen kahraman Mu-montu, bu yolculuğu sırasında hayattayken işledikleri günahlardan dolayı cezalandırılan ve sevap-

1 “Şamanist” Türklerin öbür dünya ile insanların cezalandırılması arasındaki bağlantıdan söz etmediklerinden, günah kavramının onlara yabancı olduğundan, öbür dünyanın onlara bolluk ve bereket vaat etmediği gibi ceza ile de tehdit etmediğinden, lanetli ruhların yandığı cehennemin onların inanç sistemlerinde yer almadığından söz eden araştırıcılar, cehennem kavramının Şamanist Türklere sonraki zamanlarda yabancı bir kültürel çevreden geçmiş olabileceğini ifade etmişlerdir (Tryjarski, 2012: 108). Cehennemle ilgili "tozak", "tamas", "tamu/tamug/tamuv/tama" gibi kavramların Türkçeye Farsça, Sanskritçe ve Soğdca üzerinden geçtiği düşünüldüğünde "Şamanist" Türklerin cehennemle ilgili tasavvurları, temasa geçtikleri yabancı kültürler ile benimsedikleri yabancı dinlerden aldıklarını söylemek mümkündür. Nitekim Roux da Türklerdeki cehennem inanc1nın yakın tarihlere ait olduğunu, bunun Türklere "yüksek dinler" vasıtasıyla geçtiğini ifade etmiştir (Roux, 1999: 169-170).

2 W. Bang ile Reşit Rahmeti Arat tarafindan yayımlanan eski Uygurlardan kalma türlü cehennemlerle ilgili parçalarda "inkârcı ruhlar" ile herhangi bir canlıyı öldüren "günahkâr ruhlar" 1 cehennemlerde ne tür işkencelerle cezalandırılacakları ayrıntılı bir şekilde anlatılmıştır (Bang-Rahmeti, 1934; Arat, 1991). Bu parçalar, Maniheizm ve Budizm'i benimseyen eski Uygurlar üzerinden Türk yazılı geleneğinin en eski cehennem tasvirlerine yer vermektedir. 
larından ötürü ödüllendirilen "ölüler ülkesinin insanları" ile karşılaşır. Cezalandırılan ve ödüllendirilen canlılar arasında atlar da yer almaktadır. Anlatıda günahkâr şamanlar, memurlar ve dürüst ticaret yapmayan tüccarların kaynayan katran kazanı içinde debelenerek; başkaları hakkında yalanlar yayan dedikoducu kadınların ağızları dikilerek; hafif meşrep olup kocalarına sadık kalmayan kadınların dikenli çalılara sarılarak; hırsızlık yapan erkeklerin elleri ve ayakları bağlanarak; cimri ve katı kalpli olan kadının ise zengin görünümüne rağmen açlığa mahkûm edilerek cezalandırıldığ anlatılmıştır. Hayattayken insanlara hep yardım eden kadının yoksul görünümüne rağmen mutlulukla ödüllendirildiğine de dikkat çeken anlatı, yaşarken iyi bakılmış ve semirmiş atların çıplak kayalıklara mahkûm edildiklerini; doğru dürüst bakım ve yiyecek yüzü görmemiş atların ise mümbit çayırlara salınarak ödüllendirildiklerini kaydetmiştir. “Ölüler ülkesi”ndeki ceza ve ödüller, sadece insanları değil, atları da kapsamaktadır (Harva, 2015: 287-288). Bunda, kanaatimizce, atların sahipleriyle birlikte kurganlara gömülmeleri de etkili olmuştur. Ödüllendirmeler, sadece yaşarken yapılan iyilikler için değil, maruz kalınan mahrumiyetler için de geçerlidir.

Castrén'in derlediği destanda ise Komdei-Mirgän, “yeraltı ülkesinin" efendisi İrlek Han'ın kara tilki donundaki kızının peşine düşer. Tilki, kahramanın yolunu kaybetmesine ve ayağının kırılmasına neden olur. Yeraltından çıkan ve kırk boynuzlu bir boğaya binen Jilbegän adlı dokuz baş lı bir canavar, kahramanın başını kopararak yeraltındaki evine götürür. Kahramanın kız kardeşi Kubayko, ağabeyinin cenazesine ağıt yakmak için gelir, fakat ağabeyinin başının olmadığını görünce başını geri getirmek için yeraltına inmeye karar verir. Kubayko, canavarın izlerini takip ederek, İrlek Han'ın ülkesine giden geçidi bulur. Bu geçitten aşağı inince de ilginç şeylerle karşılaşır. Bir kadın, hiç durmadan bir kaptan başka bir kaba süt boşaltmaktadır. Bu kadın, hayatı boyunca misafirlerine su karıştırılmış süt ikram etmiş olduğundan, suyu sütten ayrıştırma cezasına çarptırılmıştır. Üzerinde ne bir tutam otun, ne bir damla suyun olduğu çorak bir yere bir at bağlanmıştır, ama at buna rağmen oldukça bakımlı ve sağlıklı görünmektedir. Bu, akıllı bir adamın en kötü şartlar altında bile hayatiyetini en iyi şekilde idame ettirebileceğine işarettir. Acınacak kadar zayıf ve çelimsiz bir at, yeşil çayırların ortasında bir su kaynağının yanında otlamaya çalışmaktadır ki, bu, gerekli özen ve ihtimam gösterilmediğinde en bereketli çayırların bile bir işe yaramayacağına işaret eder. Yarım bedenli bir insan, bir ırmağa set örmeye çalışmaktadır. Bu insan bir cezaya çarptırılmış değildir. O yarım beden, çok zeki ve bilgili olan, nehirlerin önüne set çekebilen, karar verdiği her şeyi yapabilen bir insana aittir. Onun orada olmasının biricik sebebi, bir insanın aslında bazı uzuvları olmasa da çok önemli 
TÜBAR XLI / 2017-Bahar / Sibirya Halk Anlatılarının...

işler yapabileceğini göstermektir. Bir beden nehrin akıntısına kapılıp gitmektedir. Bu beden, tek başına ve sadece kendi bedenine güvenen insanın aslında çok da fazla bir şey yapamayacağını işaret etmektedir. Söz konusu beden aslında bir zamanlar güçlü, ama budala bir adama aittir ve nasıl şu anda sular onun bedeninin üzerinden akıp gidiyorsa, her şey de onun zihninden o hiçbir şeyi anlamadan öylesine akıp gitmiştir.

İrlek Han'ın kırk köşeli taş sarayına girip de yolu şaşıran Kubayko, bir atamanı takip ederek bazı boş odalardan geçtikten sonra içinde insanların olduğu odalara gelir. Odalardan birinde bütün hayatı boyunca güneş battıktan sonra, yani çalışmanın yasak olduğu saatlerde yün eğirdiği için şevkle yün eğiren yaşlı bir kadın; diğerinde sarmak için aldıkları iplik yumağının bir bölümünü kendilerine ayırıp yumağın ortasını boş bıraktıkları için hiçbir şeyle meşgul olmayan, ama bir türlü kursaklarından geçmeyen bir şeyi yutmaya çalışan kadınlar (çaldıkları ipliklerin yumaklarını şimdi sonsuza kadar yutmaya çalışacaklar, fakat hep boğazları tıkanacağı için bunu başaramayacaklardır); üçüncü odada sattıkları tereyağının daha ağır çekmesi için içine taş koyduklarından boyunları ve ellerinde büyük taşlar bağlı orta yaşlı kadınlar; dördüncü odada kendilerini asarak canlarına kıydıkları için boğazlarından bir iple direğe bağlanmış erkekler; beşincisinde eşleriyle anlaşamadıkları için intihar ettiklerinden dolayı mızrakla delik deşik edilmiş, yaralarının acısıyla bağırıp yalvaran silahlı adamlar; altıncı odada sarhoş olup kendi hayatlarına acımasızca son verdikleri için elleri bıçaklı, benzeri sesler çıkaran yaralı erkekler; yedinci odada havlayan kuduz köpekler ve kızdırdıkları kuduz köpekler tarafından 1sırılan kuduz insanlar; sekizinci odada hep kendilerini düşündükleri için evlilik hayatlarını huzursuzlukla geçiren ve cezaları da aslında birbirlerine karşı anlayışlı ve uyumlu olsalar onlara fazlasıyla yetecek olan bir örtüyü sonsuza kadar paylaşamayacak olan evli çiftler yatmaktadırlar. Dokuzuncu odada, küçük bir örtünün altında oldukça sakin bir şekilde uyuyan bir başka çift vardır. Aslında çok fakir olan bir ailenin bile birbirleriyle uyum ve huzur içinde yaşayabileceklerini göstermek için orada örnek olarak bulunmaktadırlar. Onlar, cezalandırılmak için değil, sadece kötü insanların her an daha fazla pişmanlık hissetmeleri için buradadır (Harva, 2015: 288-291).

Sibirya halk anlatılarının "ölüler ülkesi” ile işledikleri günahlardan dolayı işkence edilerek cezalandırılan ve sevaplarından dolayı ödüllendirilen ölüleri, Tıvaların "Alday-Buuçu” adlı destanında da görülmektedir. Han-Buuday, sözlüsü olan kızı almak için sefere çıtığında Kızaa-KaraHem'in aşağısına giderken birden her taraf kararır. Atı, buna binicisine, Orta Dünya'yı geçip Alt Dünya'ya indiklerini söyler. Alt Dünya'daki yolculuk sırasında tuhaf hallerde bulunan bazı insanlarla karşılaşırlar ve atı, 
bu insanların aydınlık dünyada iken yaptıklarının cezasını karanlıklar dünyasında çektikleri için tuhaf hallerde olduklarını söyler. Hayattayken insanlara dil uzatan kişi dilinden, insanlara kötü gözle bakan kişi ise gözünden demir çengelle aşılmış vaziyettedir. Hayattayken birbirleriyle geçinemeyen karı koca, iki kaya üzerinden birbirlerini tırnaklarken hayattayken sadece kız çocuğu doğuran kadın bir memesiyle çocuğunu, diğer memesiyle de bir yılanı emzirmektedir. Öte yandan, hayattayken dokuz çocuk doğuran bir kadın ise dokuz kat minder üstünde semirmiş bir şekilde yatmaktadır (Ergun ve Aça, 2004: 234-235). Sadece kız çocuğu doğuran kadının bir memesiyle bir yılan emzirmeye mahkûm edildiği "ölüler ülkesi"nde büyük bir ihtimalle hepsi de erkek olan dokuz çocuk doğuran bir kadına özel bir ihtimam gösterilmiştir.

Yukarıdaki anlatılardan ölülerin hepsinin aynı yere, yani "ölüler ülkesi"ne gittiği anlaşılmaktadır. Yeraltındaki "ölüler ülkesi”, günahlı ve günahsızların birlikte gittikleri bir yerdir. Ölüler, burada hayattayken işledikleri günahlara ve sevaplara göre ya cezalandırılıp ödüllendirilmektedirler. "Ölüler ülkesi”"nde yolculuk yapanların gördükleri bazı manzaralar, bir ödül ya da cezayı ifade etmemektedir. Örneğin, bir ırmağa set yapmaya çalışan yarım bedenli insanla çorak yerdeki oldukça bakımlı ve semiz at, insanlara bazı mesajların iletilebilmesine aracılık etmektedirler. Harva'nın aktarımları, hayattayken nimetlerden mahrum bırakılan hayvanların "ölüler ülkesi”nde nimet bolluğuyla ödüllendirileceğine dair inanca da yer vermektedir.

İnsanlara günahlardan uzak durmalarını ögütleyen, "ölüler ülkesi"nde işlenen her bir günaha, o günahın işleniş biçimine uygun bir ceza verileceğine inandırmaya çalışan, "ölüler ülkesi”nin insanları üzerinden yaşayanlara dersler veren bu tür anlatılarda öne çıkan bazı suçlar ve bu suçlara verilen cezalar şöyledir: Süte su karıştırmak (cezası, sonsuza dek sütü sudan ayrıştırmaya çalışmak), sarmak için alınan iplik yumağından yün çalmak (cezası, yün yutmaya çalışmak), çalışmanın yasak olduğu geceleri çalışmak (sonsuza kadar çalışmaya mahkûm edilmek), başkaları hakkında yalanlar yaymak, dedikodu yapmak (cezası, ağzı dikilmek), hafifmeşreplik ve eşe sadakatsizlik (cezası, dikenli çalılara sarılmak), cimrilik ve merhametsizlik (cezası, açlığa mahkûm olmak), kendini boğarak intihar etmek (cezası, boğaza geçirilen bir iple bir direğe bağlanmak), evlilikte sadece kendini düşünmek (cezası, "ölüler ülkesi”nde sonsuza dek didişip durmak) vd.

Anlatıların daha çok kadın günahkârlar üzerinde durduğu da görülmektedir. Biraz aşağıda ele alınacak cehennemle ilgili İslami anlatılarla 
TÜBAR XLI / 2017-Bahar / Sibirya Halk Anlatılarını...

Hz. Peygamber'e atfedilen bazı sözlerde de daha çok günahkâr kadınlardan söz edildiği görülecektir.

\section{2. İslamî Anlatıların Cehennem Azabı Çeken İnsanları}

Sibirya halk anlatılarının "ölüler ülkesi"nin insanları, İslami anlat1larda cehennemde azap çeken günahkâr insanlar olarak görülmektedir. Günahlarından dolayı cehennemde azap çeken ölülere yer veren anlatıların başında Hz. Muhammed'in miraca çıkışını anlatan miraçnameler, kıssalar ve masallar gelmektedir. Hz. Muhammed'e atfedilen bazı hadislerde de benzer anlatımlara yer verilmiştir. Bu tür anlatılardaki ceza nedenleri ve cezalandırma biçimleri ile Sibirya halk anlatılarındaki ceza nedenleri ve cezalandırma biçimleri arasında benzerlikler vardır.

Miraçname nüshalarındaki cehennem ateş, duman, kaynayan katran ve sulardan, dayanılamayacak derecede pis kokulardan ibarettir. Miraçnamelerde insanların cehennemde suçlarına göre cezalandırılış biçimlerinden de söz edilmiştir. Örneğin, dinin kendilerine helal kıldığı eşlerini bırakıp yabancılarla düşüp kalkanlar cehennemde ateşler içinde çırılçıplak halde bulunurlar. Onlar katran alevleri içinde feryat ederler; yüzleri yanmış, bellerinin altını yılanlar sarmıştır. Abdülvasi Çelebi nüshasında zina yapanlar temiz eti bırakıp pis, murdar etleri yiyenler şeklinde tasvir edilir. Miraçname nüshalarında haram, faiz ve yetim malı yiyenler büyük başlı, şişkin karınlı, domuz suretli, vücutlarına yılan çıyanlar dolanmış olarak tasvir edilirler (Akar, 1987: 332-333). Miraçname'nin Laleli-II nüshasında koca sözü dinlemeyen kadınların cehennemde katrana daldırılıp ateşte yakıldıklarından, ateşli topuzlarla dövüldüklerinden, zebaniler vurdukça tenlerinin yanar halde olduklarından; ağıt ve şarkı yakan kadınların dillerinin enselerinden çıkmış durumda bulunduklarından; gıybet edenlerin de baş aşağı asıldıklarından, cehennem meleklerinin onların etlerini kesip kendilerine yedirdiklerinden söz edilmiştir (Akar, 1987: 289).

Hayati Develi'nin yayınladığı başka bir manzum miraçnameye göre dünyadayken kendi çocuğunu bırakıp dadılık eden ve sütlerini satan kadınlar cehennemde memelerinden asılarak, ağıt yakıp şarkı söyleyenler dilleri çekilip kesilerek cezalandırılırlar. Bir gurup insanın karnı çok büyük ve yılan çıyanla doludur. Boyunlarında da yılan sarılı olan bu insanlara zebaniler ateş yedirmektedirler. Bunlar, dünyadayken faiz yiyenler ve tefecilik yapanlardır. Evli olup da zina yapanlar önlerindeki helal yiyeceği bırakıp haram yiyeceklerden yerler. Başkalarının gıybetini yapanlar, omuzlarından kesilen kendi etlerini yiyerek cezalandırılmaktadırlar (Develi, 1998: 87).

Miraçnamelerdeki merkezinde genellikle günahkâr kadınların yer aldığı cehennem ve cehennem azabıyla ilgili anlatımların oluşmasında, 
Türklerin eski inanç sistemlerine bağlı bir şekilde geliştirdikleri ya da farklı dinlerden alarak benimsedikleri eski tasavvurlarının yanı sıra, $\mathrm{Hz}$. Peygamber'e atfedilen miraçla ilgili bazı hadislerin de etkisi olmuştur. Hz. Ali tarafından nakledildiğine inanılan ve Şii Müslümanların hadisler için en çok başvurdukları "Bihari'l-Envar"1n sekizinci cildinde yer alan bir hadiste $^{3}, \mathrm{~Hz}$. Peygamber'in miraca götürülürken ümmetinin kadınlarından bir grup kimseyi şiddetli azap içinde gördüğünden ve bunu hatırlayarak ağladığı anlatılmıştır. Bu hadiste saçını erkeklerden gizlemeyen kadının saçlarından asılarak; kocasını inciten kadının dilinden asılarak ve boğazından cehennemin akıcı suyu boşaltılarak; kocasının yatağından kaçınan kadının memelerinden asılarak; kocasının izni olmaksızın evden çıkan kadının ateşten tandırda ayaklarından asılarak; bedeninin halk için süsleyen kadının bedeninin etini yiyerek; necis elbiseyle abdest alan, cenâbet ve hayız guslü yapmayan, temizliğe riayet etmeyen ve namazı önemsemeyen kad1nın elleri ve ayakları bağlanarak ve üzerine akrepler salınarak; zina yoluyla çocuk doğurup onu kocasına mal eden kadının ateşten bir tabuta konularak ve sağır ve dilsiz yapılarak; kendisini erkeklere sunan kadının bedeninin eti ateşten makasla önden ve arkadan kesilerek; yakınlarını başkalarına satan namussuz kadının yüzü ve elleri yakılarak ve bağırsaklarını yemeğe mahkûm edilerek; söz taşıyan ve yalan söyleyen kadının başı domuz başına, gövdesinin ise eşek gövdesine çevrilerek; makyaj yapan, şarkı söyleyen, bağırarak ağlayan ve herkesi kıskanan kadının köpek şekline sokularak ve altından ateş sokularak cezalandırıldığından söz edilmiştir. ${ }^{4}$

Miraçname nüshaları ile Hz. Peygambere atfedilen miraç konulu hadislerde sözü edilen günahkâr kadınlar, tıpkı Sibirya halk anlatılarının “ölüler ülkesi”nin günahkâr kadınları gibi, işledikleri günahlara uygun bir şekilde cezalandırılmaktadırlar. Bu durum, miraçname nüshaları ile söz

3 Hadis metni şu adresten alınmıştır: http://www.tebyan.net/index.aspx?pid=157458 (Erişim tarihi: 10.05.2016). Söz konusu hadiste yer alan günahkârlar ile bu günahkârlara cehennemde verilen cezaları anlatan diğer hadis örnekleri için bk. http://kitap.mollacami.com/kabir-alemi/konu-4862.htm (Erişim tarihi: 10.05.2016).

4 İmam Buhari’nin Semüre b. Cündüb'den aktardığı bir hadiste ise Hz. Peygamber, bir gece rüyasında iki kişi tarafından yolculuğa çıkarıldığını, bu yolculuk sırasında cehennemde azap çeken günahkârları gördügünü anlatmıştır. Cehennemde azap çeken bazı günahkârlar şunlardır: Kur'an'ı öğrendiği halde onu terk ettiği ve uykuyu namaza tercih ettiği için kafası ezilerek cezalandırılan adam; evinden çıktığında her tarafa yayılacak yalanlar söylediği için şakakları, gözleri ve burnu demirle yarılarak cezalandırılan adam; zina ettikleri için çıplak bir şekilde kızgın firına atılarak cezalandırılan erkekler ve kadınlar; faiz yediği için taş yutturularak nehirde yüzdürülen adam (Tanevi, 1989: 69-70). İşlenen diğer günahların cehennemdeki karşllıklarıyla ilgili anlatımlar için ayrıca bk. (Tanevi, 1989: 7-75) 
TÜBAR XLI / 2017-Bahar / Sibirya Halk Anlatılarının...

konusu hadislerin "kadın", "günah", “cehennem” ve "ceza" söz konusu olduğunda, tıpkı Sibirya halk anlatılarında olduğu gibi, erkek egemen bir bakış açısına sahip olduğunu göstermektedir. Söz konusu anlatılar, sanki cehennemi kadınlarla doldurarak orada erkeklere yer birakmak istemez gibidirler.

Miraçname nüshaları ile hadislerin cehennemde işkence edilerek cezalandırılan günahkârları, elbette sadece kadınlar değildirler. Haram, faiz ve yetim malı yiyen erkekler büyük başlı, şişkin karınlı, domuz suretli, vücutlarına yılan çıyanlar dolanmış olarak; eşlerini bırakıp yabancılarla zina yapan erkekler ise cehennemde ateşi içinde çıplak olarak tasvir edilirler.

Sibirya halk anlatılarının kahramanlarının “ölüler ülkesi”nde yolculuk etmeleri ve orada dünyada yaptıklarına göre cezalandırılan ya da mükâfatlandırılan insanlarla karşılaşmaları, Türkiye Türklerinden derlenmiş bir masala da konu edilmiştir. Masal, Saim Sakaoğlu tarafından Gümüşhane ve Bayburt bölgesinden derlenmiş ve "Konuşan Bebek Masalı" adıyla yayımlanmıştır (Sakaoğlu, 2002: 303-304). Masalda, oğlunun göl kenarında bulduğu kurbağa donundaki kızı, karısının tavsiyesi üzerine almayı arzulayan ve bunun içinde oğlunu öldürmek isteyen bir padişah, bir cadı karısının tavsiyesi üzerine oğluna, öte dünyadaki annesinden (anne, kocası olan padişaha oğlunu öldürerek getirdiği kızı almasını söylemiş, fakat çok geçmeden ölmüş̧ür) anahtar alıp getirmesini buyurur. Oğlan, kurbağa donundaki karısının tavsiyesi üzerine bir gül çubuğu alarak suyun k1yısına gider. Çubuğu suya vurduğunda kurbağa donundaki karısının annesi çıkar. Oğlan, kaynanasından eşeği ister ve bu eşeğe binerek anahtarı almaya gider. Yolda bir adamın etlerini kargaların kopardığını görür ve adama ne olduğunu sorar. Adam da gitmesini ve dönüşte anlatacağını söyler. Öteki dünyada yoluna devam eden oğlan, annesini cayır cayır yanarken görür. Bunun sebebi, kadının kocasına oğlunu öldürerek karısını almasını söylemesidir. Oğlan, anahtarın odanın eşiğinin altında olduğunu öğrenir. Yoluna devam eden oğlan, sütleri bir kaptan öbürüne boşaltan bir kadına rastlar. Bunun sebebi, kadının yaşarken süte su katmasıdır. Geri dönüş yolunda kargaların parçaladığı adama tekrar rastlar ve bunun yaşarken zavallı hayvanlara eziyet etmesinden kaynaklandığını öğrenir. Süte su kattığı için sütü sudan ayırma cezasına çarptırılan kadın, Sibirya halk anlatılarının “ölüler ülkesi”yle ilgili anlatımlarda da yer almıştır.

Miraçname nüshaları, miraçla ilgili hadisler ve "Konuşan Bebek Masalı", Sibirya halk anlatılarının "ölüler ülkesi”nin insanlarını, İslamî dönem anlatılarında karşımıza cehennemde korkunç cezalara çarptırılan günahkârlar olarak çıkmaktadır. Sibirya halk anlatılarının "ölüler ülkesi", ölen her canlının (insanlar, atlar vd.) gideceği bir yerken, İslamî anlatıların 
“cehennem"i sadece günahkâr insanların gideceği bir yerdir. Sibirya halk anlatılarının kötülerin cezalandırılıp iyilerin ödüllendirildiği "ölüler ülkesi", genel anlamda "öteki dünya" iken, İslamî anlatıların öldükten sonra azap ya da işkence çeken günahkâr insanlarının bulundukları yer, "cehennem"dir.

\section{3. "Ölüler Ülkesi”nin İnsanları ve "Cehennem"in Azap Çeken İnsan- larıyla İlgili Anlatıların Kaynaklarına Dair}

Sibirya halk anlatılarının "ölüler ülkesi”nin insanları ile İslamî anlatıların cehennem azabı çeken insanları arasındaki benzerlikler, bu benzerliğin nedenlerini, anlatıların köken ya da kaynaklarını da tartışmayı gerektirmektedir. Harva'nın da ifade ettiği gibi, benzerlikleri her şeyden önce evrensel değerlerde aramak gerekir. Bu benzerlikleri, hatırlanamayacak kadar eski zamanlara dayanan ortak bir mirasın ürünü olarak görmek de mümkündür. Bu tür tasavvur ve anlatıların, tarihin derinliklerinde belli bölgelerde meydana gelerek geniş bir alana yayılmış olmaları da mümkündür. Fakat "ölüler ülkesi" ya da "yeraltı dünyası"na inişlerin, hangi inanç sistemi esasında anlatılırsa anlatılsın, "şamancıl" bir yapıya sahip olduğu da unutulmamalıdır.

“Ölüler ülkesi”ne iniş temasının dünya anlatılarındaki bilinen en eski örnekleri, Sümer ve Babil anlatılarında görülmektedir. Sümer mitolojisinde göŏün kraliçesi İnanna'nın, üzerinde kız kardeşi tanrıça Ereşkigal'in egemenlik sürdügü “dönüşü olmayan ülke”ye, yani “ölüler ülkesi”ne inmeye karar verdiği anlatılırken Babil mitolojisinde ise ölüler ülkesine inenin İştar olduğundan söz edilmiştir (Hooke, 2002: 26-27, 48-51). Göklerin tanrıçası İștar'ın “ölüler ülkesi”ne iniş sebebi, orayı ele geçirmektir. Dünyadaki statü ve konumları ne olursa olsun, bütün insanların ölümden sonra bir arada yer alacakları; kötülerin cezalandırılıp iyilerin ödüllendirileceği "ölüler diyarı" (Arallu), ölülere ait ruhların yiyecek olarak toprak, ekmek olarak da kil yediği, elbise olarak kuş kanatlarına sahip oldukları karanlık bir yerdir. Bereket ve aşk tanrıçası olan İştar'ın, kardeşi Ereşkigal tarafindan yeraltı dünyasına hapsedilmesiyle yeryüzündeki insanlarla hayvanların çoğalması durur (Taşpınar, 2003: 37-38). “Ölüler diyarı”na inerek birer ölüye dönüşen İnanna ile İștar, "hayat ekmeği” ve "hayat suyu" vas1tasıyla dirilerek tekrar diriler dünyasına çıkar.

Sümer ve Babil mitolojilerinin "ölüler diyarı", eski Yunan anlatılarında "karanlık yeraltı krallığı" (Hades) olarak karşımıza çıkmaktadır. Hades "Asphodel", "Tartarus" ve "Elysium" adlı üç bölümden oluşur. "Tartarus" adlı bölümde günahkârlar cezalandırılmaktadırlar. Cezalandırılanlar arasında Yunan mitolojisinin ünlü titanları da yer almaktadır: "Apollon ile 
Artemis'in annesi Leto'ya saldıran Tityus, Hades'in 3.636 hektarlık bir alanına mıhlanmış ve ciğeri akbabalarca yenilmektedir. Hades'ten firar etmek için hileye başvurmuş olan Sisyphos, ebediyen bir kayayı yokuş yukarı yuvarlamaya mahkûm edilmiştir ki kaya, tam tepeye ulaşmışken her seferinde tekrar aşağı yuvarlanır. Onun yanında, Olympos Kraliçesi Hera'ya tecavüz girişiminde bulunduğu için ateşten bir çembere bağlanmış İksion vardır. Yakınlarda bir yerde ise, kendi oğlunu pişirip tanrılara sunan Tantalos vardır. O, bir gölün üzerindeki ağaçta asılıdır, açlık ve susuzluk içindedir, ama ne göldeki suya ne de ağaçtaki meyveye uzanabilir. Erken dönem Yunan yazarları, kimi zaman onu yalnızca boynuna taş bağlayarak cezalandırmışlardır. Gölden elekle su çekmeye çalışanlar ise, kocalarını firketeleri ile öldürmüş olan, kimi zaman elli, kimi zaman üç kız kardeş olarak söz edilen Danaidler'dir (Turner, 2004: 41-42).

Yunan mitolojisinin bazı ünlü titanlarının "karanlık yeraltı krallığı"nda işledikleri günahlarından ötürü sonsuza dek cezalandırıldıklarını anlatan bu bölüm, Sibirya halklarıyla başta Anadolu Türkleri olmak üzere Müslüman toplulukların “ölüler ülkesi”yle "cehennem"de işkence edilerek cezalandırılan insanlarla ilgili anlatılarını etkileyebilecek türden bir anlatımdır. "Ölüler ülkesi”"ne iniş teması, Sümer, Babil ve Yunan mitolojilerine kadar uzanmaktadır. Bunlardan sadece Yunan mitolojisinin "karanlık yeraltı krallığı" Hades'in Tartaros adlı bölümünde işledikleri suçlara göre ebedi cezalara çarptırılan varlıklardan (titanlardan) söz edilmiştir.

Sibirya halklarının anlatılarında yer alan "ölüler ülkesi”nin günahkâr insanları ile İslamî anlatıların "cehennem"de azap çeken günahkâr insanlarının kökenleriyle ilgili sorgulamalarda Budizm'i de göz önünde tutmak gerekir. Budizm üzerine yaptığı çalışmalarıyla tanınan Ruben, iyilerin ve kötülerin öteki dünyada cezalandırılacağı ya da ödüllendirileceği düşüncesinin, Buda'dan daha önceki dönemlerde yazılmaya başlanmış olan Upanişad derlemelerinde görüldüğünü, Upanişadların yazıldığı dönemlerden çok daha önceleri de yerli halkların inançlarında buna benzer düşüncelerin olduğunu kaydetmiştir. Ruben'e göre bu inançların başında, ölülerin de kendilerine ait devletleri olduğu inanc1 gelmiştir. Bir insanın ölünce oraya gidip orada yaşadığına inanılmıştır. İnsanların öldükten sonra göğe yükseleceği ve hayatları boyunca yaptıkları iyi ve kötü işlerin karşılığını cennete ya da cehenneme gitmekle alacakları düşüncesinin İ.Ö. 9. 6. yüzyıllara ait olduğunu kaydeden Ruben'e göre bu dönemlerde insanlar arasında geçerli olan düşünce, iyilerin cennete, kötülerin ise cehenneme gideceği, öteki dünyadaki mutluluğun bu dünyadakinden çok farklı olduğu düşüncesidir. Ruben, daha sonraki dönemlerde cennet ve cehennemin var- 
lığına duyulan bu inancın, hem Brahman hem de Budacı keşişlerin üzerinde en fazla durdukları konu olduğunu, Budacı keşişlerin bu konuda çok daha ileri giderek cennet ve cehennemi anlatan özel bir bilim dalı geliştirdiklerini yazmıştır. Bu bilim dalında cehennem en ince ayrıntılarına varıncaya kadar anlatılmış ve günahkâr insan çeşitlerine göre cehennem türleri belirlenmiştir (Ruben, 1995: 79).

Budacı keşişlerin en ince ayrıntılarına kadar anlattıkları ve günahkâr insan çeşitlerine göre sınıflandırdıkları cehennem tasavvurlarının Sibirya halklarının “ölüler ülkesi”nin insanları ve Müslüman toplumların cehennemin azap çeken insanlarıyla ilgili anlatıları üzerinde etkili olduğu görüşünü destekleyen hususlardan birisi de Budacı anlatıların kadınla ilgili olumsuz bakış açısıdır. Bu tür anlatılarda kadın, doğası gereği kötü bir varlıktır. Kadınlara karşı duyulan en küçük istek bile insanları felaketlere sürükleyebilir. Bir kadına bir tek kelime bile yazıp göndermek, bir insanın kör ya da ahmak olarak yeniden doğmasına neden olabilmektedir (Ruben, 1995: 80). Burada, Sibirya halklarıyla Müslüman halkların "ölüler ülkesi”nin insanları ve "cehennem"in azap çeken günahkâr insanlarıyla ilgili anlatılarında günahlarından dolayı işkence edilerek cezalandırılan kadınlardan sıklıkla söz edildiğini bir kez daha hatırlamakta yarar vardır.

\section{Sonuç}

Sibirya halklarının "ölüler ülkesi”nin insanları ile İslamî anlatıların "cehennem"de azap çeken günahkâr insanları arasında ceza nedenleri ve cezalandırılma biçimleri bakımından önemli benzerlikler vardır. İslamlaşan Türk grupları bu tür anlatıları, daha İslamlaşmadan önce Şamanizm, Budizm, Hrıstiyanlık, Maniheizm gibi Güney Asya ve Yakın Doğu dinleri üzerinden benimsemişler, İslamlaşma ile birlikte bunları, Müslüman toplumların yine benzer kaynaklardan beslenerek geliştirdikleri yeni unsurlarla zenginleştirerek İslam inancı doğrultusunda sürdürmüşlerdir.

“Ölüler ülkesi”ne iniş temasının en eski örnekleri Sümer, Babil ve Yunan kaynaklarına kadar gitmektedir. Bunlar içerisinde sadece Yunan kaynaklarının anlatımlarında "ölüler ülkesi"nde suçlarından dolayı cezalandırılan "titan"lardan söz edilmektedir. Cehennem ve cehennemde azap çeken günahkârlarla ilgili tasavvurların geliştirilmesinde Budist rahiplerin de önemli bir yere sahip oldukları görülmektedir.

“Ölüler ülkesi” ya da yeraltı dünyasına iniş ve orada işkence edilerek cezalandırılan günahkâr insanlara rastlama teması, hangi toplum ya da inanç sistemine ait gösterilirse gösterilsin, Eliade'nin de ifade ettiği gibi, "Şamancıl" bir karaktere sahiptir. Şamanların "cehennem"deki işkencelere 
TÜBAR XLI / 2017-Bahar / Sibirya Halk Anlatılarının...

tanık oluşlarının, Güney Asya ve eski Yakın Doğu kültürlerinden etkilenmiş olsalar bile, dünyanın her yerinde ilk olarak Şamanların dirilere aktardığ1 yeraltı topografyasının kimi betimlemeleriyle örtüştügüne dikkat çeken Eliade'ye göre, insanların ölümden sonraki yazgılarını öğrenmek üzere girişilen en ünlü yeraltına inişlerden birkaçı "Şamancıl”" yapıdadır; yani, Şamanların esrime teknikleri kullanılarak gerçekleştirilmiştir (Eliade, 1999: 264).

\section{KAYNAKÇA}

AKAR, Metin (1987), Türk Edebiyatında Manzum Mi'râc-nâmeler, Kültür ve Turizm Bakanlığı Yayınları, Ankara.

ARAT, Reşit Rahmeti (1991), Eski Türk Şiiri, Türk Tarih Kurumu Yayınları, Ankara.

BANG, W.-Rahmeti, R. (1934), “Türlü Cehennemler Üzerine Uygurca Parçalar”, İstanbul Üniversitesi Türkiyat Araştırmalar Enstitüsü Türkiyat Mecmuası, IV, s. 251-263.

DEVELİ, Hayati Develi (1998), "Eski Türkiye Türkçesi Devresine Ait Manzum Bir Miracnâme", İstanbul Üniversitesi Edebiyat Fakültesi Türk Dili ve Edebiyatı Dergisi, 28 (1), s. 81-228.

ELİADE, Mircea (1999), Şamanizm. İlkel Esrime Teknikleri, Çev.: İsmet Birkan, İmge Kitabevi, Ankara,

ERGUN, Metin-Aça, Mehmet (2004), Tıva Kahramanlık Destanları I, Ankara: Akçağ Yayınları.

HARVA, Uno (2015), Altay Panteonu Mitler, Ritüeller, Inançlar ve Tanrlar, Çev.: Ömer Suveren, Doğu Kütüphanesi, İstanbul.

HOOK, Samuel Henry (2002), Ortadoğu Mitolojisi Mezopotamya Mısır Filistin Hitit Musevi Hristiyan Mitosları, Çev.: Alâeddin Şenel, İmge Kitabevi, İstanbul.

ROUX, Jean-Paul (1999), Eskiçağ ve Ortaçağda Altay Türklerinde Ölüm, Çev.: Aykut Kazancigil, Kabalcı Yayınevi, İstanbul.

RUBEN, Walter (1995), Eski Metinlere Göre Budizm (Budacılı̆̆ın Diyalektik Yorumu), Çev.: Lütfü Bozkurt, Okyanus Yayıncılık, İstanbul.

SAKAOĞLU, Saim (2002), Gümüşhane ve Bayburt Masallarl, Akçağ Yayınları, Ankara.

TANEVİ, Eşref Ali (1998), Dünyada ve Ahirette Amellerin Karşılı̆̆ı, Seha Neşriyat, Ankara. 
24

TÜBAR XLI / 2017-Bahar / Prof. Dr. Mehmet AÇA

TRYJARSKİ, Edward (2012), Türkler ve Ölüm Geçmişten Bugüne Türklerde Ölüm Kültürü, Çev.: Hafize Er, Pinhan Yayıncılık, İstanbul.

TURNER, Alice K. (2004), Cehennemin Tarihi, Çev.: Ayhan Sargüney, Ayrıntı Yayınları, İstanbul. 